\author{
Research Article \\ www.ijrap.net (ISSN:2229-3566)
}

\title{
PHARMACEUTICAL STUDY OF VANGA BHASMA
}

Manish Kumar Saini ${ }^{1 *}$, Meemansa ${ }^{2}$, Parimi Suresh ${ }^{3}$

${ }^{1}$ Assistant Professor, Department of Rasa Shastra and Bhaishajya Kalpana, SDAMCH and RC, Mathura, Uttar Pradesh, India

${ }^{2}$ Assistant Professor, Department of Prasuti Tantra and Striroga, SDAMCH and RC, Mathura, Uttar Pradesh, India

${ }^{3}$ Ex-Professor, Department of Rasa Shastra and Bhaishajya Kalpana, National Institute of Ayurveda, Jaipur, Rajasthan, India

Received on: 20/07/20 Accepted on: 29/08/20

\author{
*Corresponding author \\ E-mail: manishravi007@gmail.com
}

DOI: $10.7897 / 2277-4343.1105145$

\begin{abstract}
Pharmaceutical study gives emphasis to prepare drugs in a standard manner and to dispense it. Vanga is classified as a Puti Loha. Here the Puti means bad smell, obnoxious or dirty. All three metals mentioned in this group emit obnoxious smell, while they are melting. Vanga has been widely described in our texts and several therapeutic properties have been stated. Much importance has been given to its efficacy as Vrishya and as a therapy for Meha Roga. The Aim of this study is to prepare Vanga bhasma as per classical guidelines. Raw Vanga metal, plant materials and other drugs used for shodhana, marana, Jarana were collected mainly from pharmacy, N.I.A., Jaipur. Buttermilk (Takra) and Gomutra were obtained from nearby shop and cow husbandry. The Vanga bhasma was prepared following Reference of Siddha Bhaishaja Mani Mala in the Department of Rasa Shastra and Bhaishajya Kalpana, N.I.A., Jaipur. In present study total 470 gm of raw Vanga was taken, after Shodhana process 463 gm Vanga was obtained. Further by the process of Jarana 440 gm Vanga was yield. From which 420 gm was used in Marana process, from which ultimately total bhasma of Vanga obtained was $438 \mathrm{gm}$.
\end{abstract}

Keywords: Vanga Bhasma, Shodhana, Marana, Jarana

\section{INTRODUCTION}

Pharmaceutics is the science as well as an art of preparing and dispensing drugs. The achievement of treatment depends upon skillful preparation of the drug by using authentic material and following the traditional processes. Ayurvedic pharmaceutics is primarily deals with plant processing and mineral processing. The methods involved in mineral processing are Shodhana, Marana, Jarana and Satvapatana etc. The aim of Ayurvedic pharmaceutics is drug manufacturing by following authenticated classical formulations, in terms of ingredients, media and procedures.

In Ayurvedic classics Lohas are defined as, "Luh Apakarshanat Iti Loha" means which is obtained by extraction from ores or which extracts disease conditions from the body. There are seven metals described in classical literature i.e. Swarna, Rajata, Tamra, Loha, Vanga, Naga and Yashada. These Dhatus classified in Shuddha Loha, Puti Loha and Mishra Loha. The metals having low melting point and produce bad odour on heating are described under Puti Loha ${ }^{1}$. Vanga is one of such metal having wide range of therapeutic values. Generally, the literature prescribes two types of Shodhana process for most of the drugs i.e. Samanya and Vishesha. Almost all classics described Kshepana/Dhalana (Quenching) process for Shodhana especially for the Puti Loha which are having low melting point. Metals are heated to molten state and poured into specific liquids is known as Dhalana/Quenching ${ }^{2}$. For Puti Loha the procedures for Marana will have to be supervened by Shodhana and Jarana etc pre pharmaceutical and intermediary processes. Vanga Bhasma is having Tikta, Ruksha, Ushna Guna and Prameha nashana, Medoghnam properties ${ }^{3}$.

\section{Aims and Objectives of Pharmaceutical Study}

To prepare the Vanga Bhasma as per the classical guidelines

\section{MATERIALS AND METHODS}

Collection and Preparation of Required Materials for Samanya Shodhana (simple purification) and Vishesha Shodhana (Special purification)

Vanga (Tin), all plant materials, Tila Taila were procured from Rasayana Shala; Pharmacy of National Institute of Ayurveda, Jaipur.

\section{Collection of Takra}

Takra (Buttermilk) was collected from the Saras dairy under Rajasthan Co-operative Dairy federation, Jaipur, for the further use in Shodhana of Vanga.

\section{Collection of Gomutra}

Gomutra (Cow urine) was collected early morning from the Goshala, local Cow husbandry, Jaipur. Cow urine was kept in glass jar for 1 hour, before using it for Dhalana process; it was strained through a cloth piece.

\section{Preparation of Kanji}

Kanji (Sour rice gruel) was prepared in departmental lab N.I.A., Jaipur. 
Procedure: In order to prepare Kanji, Firstly Shali rice $(1 \mathrm{~kg})$ cooked with 5 times of water $(5 \mathrm{~kg})$ and total cooked rice obtained was $4.5 \mathrm{~kg}$. Then Mustard oil $(200 \mathrm{ml})$ was heated in an iron pan and Hingu (Asafetida-50 gm), mustard seeds (250 gm), Haridra (turmeric- $100 \mathrm{gm}$ ) and bamboo leaves (20 in number) were added to it. The same was transferred to the cooked Shali rice. Rock Salt (20 gm) and the radish (500 gm) which was chopped into small pieces were added to the cooked rice. Three times of water was added to the cooked cooled rice (almost $13.5 \mathrm{~kg}$ ). Whole material was transferred to a sterile storage container, which was previously fumigated by dhoopana karma. The container was tightly packed by clay and cloth and allowed for fermentation at room temperature. The completion of the process was detected by burning matchstick extinguishing test. After the completion of process, the supernatant clear liquid was siphoned out by using tube. Fermentation process material was filtered through the cotton cloth and filtrate was kept in another clean Jar. Total kanji obtained was 12 liters. $^{4}$

\section{Preparation of Kulattha Kwatha}

Kulattha Kwatha (horse gram decoction) was prepared following Sharangadhara Samhita guidelines ${ }^{4-5}$. The Kulattha was procured from local market, hence the Kulattha is hard to cook hence they were reduced to coarseness and needed to be soaked overnight for proper cooking. For preparing the kwatha 16 times of water was added. After heating, total volume of $6 \mathrm{~L}$ was obtained.

\section{Preparation of Nirgundi Patra Swarasa}

Nirgundi patra (Leaves of Vitex negundo Linn.) were collected from local garden and though it is difficult to squeeze out the juice (Swarasa) from crushed leaves, 1-liter water was added to $5 \mathrm{~kg}$ of leaves and 3 liters of Juice extracted.

\section{Collection of Jarana dravyas}

Here Jarana means to assimilate the herbal drug materials in the melted Vanga metal. Haridra (Turmeric), Ajawain Lavanga, Pippali Chhal (Bark), Imali Chhal, Jeeraka and Apamarga are the seven Jarana dravya, those were collected from the NIA pharmacy in dried form on the basis of classical text Siddha Bhaishaja Manimala.

\section{Collection of Marana Dravyas}

Marana is the process of making bhasma, for this Kumari Swarasa (Aloe vera juice) was needed; collected from Herbal Garden, N.I.A., Jaipur.

Methods Adopted in Vanga Shodhana, Jarana and Marana:
- The method mentioned in Rasa Ratna Samucchaya was followed for Samanya and Vishesha Shodhana of Vanga.

- The method mentioned in Siddha Bhaishaja Manimala was followed for the Jarana of Vanga.

- The method mentioned in Rasamrita was followed in Marana of Vanga.

\section{Pharmaceutical Study}

All the steps of Shodhana, Jarana and Marana are included in pharmaceutical study.

\section{Samanya Shodhana of Vanga}

In Samanya Shodhana total 5 procedures are included according to media that are; respectively Shodhana in Tila Taila (Sesame oil), Takra (Buttermilk), Gomutra (Cow-urine), Kanji (Sour rice gruel), Kulattha Kwath (horse gram decoction) as per Rasa Ratna Sammucchya ${ }^{6}$.

\section{Principle: Dhalana/Kshepana (Quenching)}

Procedure: Pittahara Yantra was prepared by using Ulukhala (Mortar) covered with a Sharava (Shallow earthen vessel) with a hole in center. Tila taila etc. were taken double to amount of Vanga (V/W) was filled into Pittahara Yantra, in which melted Vanga metal to be poured. Raw Vanga was taken in long handled iron ladle (Loha Darvi) and heated on Gas stove. After complete melting it was immediately poured in Taila, which was filled in the Pittahara Yantra this is called Dhalana. Then Vanga was collected from media and same process was repeated again. The process was repeated 7 times with Taila, and the same process was done with other liquid media in order of Takra, Gomutra, Kanji and Kulattha Kwatha. (Table 1 to 5)

\section{Precautions}

For every time in Dhalana (quenching), fresh liquid media was taken. After Dhalana in each media, the Vanga was washed with hot water to remove excess oil, Takra etc. Vanga was weighed before and after every quenching by using digital weighing machine. Temperature of liquid media, before and after quenching was measured by using thermometer. Temperature of Vanga was also documented before quenching, at the time when it starts melting and when it completely melted by pyrometer. Time duration was also noted in every Dhalana process, and the time when it started melting and completely melted were also documented. $\mathrm{pH}$ of media was also checked and noted before and after quenching (Excluding Taila, because $\mathrm{pH}$ is not applicable for it). The whole procedure was observed keenly for detailed behavioral patterns of the metal as well as the media.

\section{OBSERVATION}

Table 1: Observations of Vanga Shodhana in Tila Taila during Dhalana process

\begin{tabular}{|c|c|c|c|c|c|c|c|c|c|}
\hline S. No. & \multicolumn{2}{|c|}{ Wt of Vanga (gm) } & \multicolumn{2}{c|}{$\begin{array}{c}\text { Volume of oil } \\
(\mathbf{m l})\end{array}$} & \multicolumn{2}{c|}{ Temp. of oil $\left.\mathbf{(}^{\mathbf{}} \mathbf{C}\right)$} & \multicolumn{2}{c|}{$\begin{array}{c}\text { Started melting and completely melted } \\
\text { at which min and at what temp }\left({ }^{\mathbf{0}} \mathbf{C}\right)\end{array}$} & $\begin{array}{c}\text { Specific } \\
\text { gravity }\end{array}$ \\
\hline & Before & After & Before & After & Before & After & Started melting & Completion & \\
\hline $\mathbf{1 .}$ & 470 & 472.2 & 800 & 795 & 21.2 & 52 & $4: 33(152)$ & $6: 30(240)$ & 0.956 \\
\hline $\mathbf{2 .}$ & 472.2 & 473.6 & 800 & 793 & 21.2 & 59 & $2: 29(216)$ & $4: 05(245)$ & 0.957 \\
\hline $\mathbf{3}$ & 473.6 & 475 & 800 & 793 & 21.2 & 62 & $2: 47(193)$ & $3: 45(228)$ & 0.959 \\
\hline $\mathbf{4 .}$ & 475 & 476 & 800 & 795 & 21.2 & 53 & $2: 43(185)$ & $4: 17(236)$ & 0.958 \\
\hline $\mathbf{5 .}$ & 476 & 476.8 & 800 & 796 & 21.2 & 64 & $2: 05(170)$ & $4: 15(234)$ & 0.961 \\
\hline $\mathbf{6 .}$ & 476.8 & 477 & 800 & 794 & 21.2 & 58 & $3: 22(158)$ & $4: 25(204)$ & 0.959 \\
\hline $\mathbf{7 .}$ & 477 & 477.3 & 800 & 792 & 21.2 & 51 & $3: 38(136)$ & $4: 53(230)$ & 0.958 \\
\hline
\end{tabular}


Table 2: Observations of Vanga Shodhana in Takra during Dhalana process

\begin{tabular}{|c|c|c|c|c|c|c|c|c|c|c|c|}
\hline \multirow[t]{2}{*}{ S. No. } & \multicolumn{2}{|c|}{ Wt of Vanga (gm) } & \multicolumn{2}{|c|}{$\begin{array}{l}\text { Volume of } \\
\text { Takra (ml) }\end{array}$} & \multicolumn{2}{|c|}{$\begin{array}{l}\text { Temperature of } \\
\text { Takra }\left({ }^{0} \mathrm{C}\right)\end{array}$} & \multicolumn{2}{|c|}{$\begin{array}{c}\text { Started melting and completely } \\
\text { melted at which min and at what } \\
\text { temperature }\left({ }^{0} \mathrm{C}\right)\end{array}$} & \multicolumn{2}{|c|}{$\begin{array}{l}\mathrm{pH} \text { of } \\
\text { media }\end{array}$} & \multirow[t]{2}{*}{$\begin{array}{l}\text { Specific } \\
\text { gravity }\end{array}$} \\
\hline & Before & After & B & $\mathbf{A}$ & B & $\mathbf{A}$ & Started melting & Completion & B & $\mathbf{A}$ & \\
\hline 1. & 476 & 478.2 & 800 & 785 & 21.1 & 45 & $1: 40(164)$ & $6: 36(232)$ & 4.4 & 4.3 & 1.0086 \\
\hline 2. & 478.2 & 481.7 & 800 & 790 & 21.1 & 46 & $3: 26(167)$ & $10: 15(252)$ & 4.4 & 4.5 & 1.0085 \\
\hline 3. & 481.7 & 483 & 800 & 786 & 21.1 & 44 & $4: 38(140)$ & $13: 50(278)$ & 4.4 & 4.6 & 1.0087 \\
\hline 4. & 483 & 484.3 & 800 & 791 & 21.1 & 47 & $4: 10(156)$ & $15: 00(288)$ & 4.4 & 4.6 & 1.0088 \\
\hline 5. & 484.3 & 486 & 800 & 789 & 21.1 & 45 & $4: 22(134)$ & $13: 15(276)$ & 4.4 & 4.5 & 1.0088 \\
\hline 6. & 486 & 488.9 & 800 & 785 & 21.1 & 43 & $4: 43(140)$ & $13: 20(290)$ & 4.4 & 4.6 & 1.0090 \\
\hline 7. & 488.9 & 492 & 800 & 790 & 21.1 & 41 & $5: 50(136)$ & $13: 50(255)$ & 4.4 & 4.5 & 1.0090 \\
\hline
\end{tabular}

Table 3: Observations of Vanga Shodhana in Gomutra during Dhalana process

\begin{tabular}{|c|c|c|c|c|c|c|c|c|c|c|c|}
\hline \multirow[t]{2}{*}{ S. No. } & \multicolumn{2}{|c|}{$\begin{array}{l}\text { Wt of Vanga } \\
\text { (gm) }\end{array}$} & \multicolumn{2}{|c|}{$\begin{array}{c}\text { Volume of } \\
\text { Gomutra(ml) }\end{array}$} & \multicolumn{2}{|c|}{$\begin{array}{l}\text { Temperature. of } \\
\text { Gomutra }\left({ }^{\circ} \mathrm{C}\right)\end{array}$} & \multicolumn{2}{|c|}{$\begin{array}{l}\text { Started melting and completely } \\
\text { melted at which min and at what } \\
\text { temperature }\left({ }^{0} \mathrm{C}\right)\end{array}$} & \multicolumn{2}{|c|}{ pH of media } & \multirow[t]{2}{*}{$\begin{array}{l}\text { Specific } \\
\text { gravity }\end{array}$} \\
\hline & B & $\mathbf{A}$ & B & $\mathbf{A}$ & $\mathbf{B}$ & $\mathbf{A}$ & Started melting & Completion & B & $\mathbf{A}$ & \\
\hline 1. & 480 & 483.1 & 800 & 784 & 27 & 39 & $2: 16(204)$ & $8: 20(223)$ & 8.1 & 8.2 & 1.0149 \\
\hline 2. & 483.1 & 485 & 800 & 790 & 27 & 43 & $5: 16(150)$ & $11: 14(210)$ & 8.1 & 8.2 & 1.0151 \\
\hline 3. & 485 & 486.2 & 800 & 795 & 27 & 40 & $4: 38(178)$ & $11: 20(240)$ & 8.1 & 8.2 & 1.0156 \\
\hline 4. & 486.2 & 459.3 & 800 & 720 & 27 & 39 & $4: 47(190)$ & $9: 30(279)$ & 8.1 & 8.4 & 1.0155 \\
\hline 5. & 459.3 & 461 & 800 & 779 & 27 & 39 & $5: 40(162)$ & $11: 02(265)$ & 8.1 & 8.3 & 1.0155 \\
\hline 6. & 461 & 461.7 & 800 & 791 & 27 & 42 & $4: 49(169)$ & $11: 18(248)$ & 8.1 & 8.3 & 1.0152 \\
\hline 7. & 462.9 & 464.4 & 800 & 788 & 27 & 42.3 & $4: 35(160)$ & $9: 55(210)$ & 8.1 & 8.4 & 1.0148 \\
\hline
\end{tabular}

Table 4: Observations of Vanga Shodhana in Kanji during Dhalana process

\begin{tabular}{|c|c|c|c|c|c|c|c|c|c|c|c|}
\hline \multirow[t]{2}{*}{ S. No. } & \multicolumn{2}{|c|}{$\begin{array}{c}\text { Wt of Vanga } \\
\text { (gm) }\end{array}$} & \multicolumn{2}{|c|}{$\begin{array}{l}\text { Volume of Kanji } \\
\text { (ml) }\end{array}$} & \multicolumn{2}{|c|}{$\begin{array}{l}\text { Temperature. of } \\
\text { Kanji }\left({ }^{0} \mathrm{C}\right)\end{array}$} & \multicolumn{2}{|c|}{$\begin{array}{l}\text { Started melting and completely } \\
\text { melted at which min and at what } \\
\text { temperature }\left({ }^{0} \mathrm{C}\right)\end{array}$} & \multicolumn{2}{|c|}{ pH of media } & \multirow[t]{2}{*}{$\begin{array}{l}\text { Specific } \\
\text { gravity }\end{array}$} \\
\hline & B & $\mathbf{A}$ & $\mathbf{B}$ & $\mathbf{A}$ & B & $\mathbf{A}$ & Started melting & Completion & $\mathbf{B}$ & $\mathbf{A}$ & \\
\hline 1. & 452.5 & 454.2 & 800 & 790 & 26.6 & 42 & $2: 50(180)$ & $8: 54(202)$ & 3.4 & 3.6 & 1.0751 \\
\hline 2. & 454.2 & 457.2 & 800 & 792 & 26.6 & 46.8 & $3: 37(146)$ & $9: 19(236)$ & 3.4 & 3.5 & 1.0757 \\
\hline 3. & 457.7 & 458.3 & 800 & 790 & 26.6 & 51.8 & $2: 54(168)$ & $7: 38(226)$ & 3.4 & 3.5 & 1.0756 \\
\hline 4. & 458.3 & 459.8 & 800 & 786 & 26.6 & 50.8 & 4:04 (180) & $9: 17(213)$ & 3.4 & 3.5 & 1.0756 \\
\hline 5. & 459.8 & 461.7 & 800 & 788 & 26.6 & 48.3 & $2: 33(179)$ & $8: 15(221)$ & 3.4 & 3.6 & 1.0758 \\
\hline 6. & 461.7 & 463.6 & 800 & 790 & 26.6 & 47.8 & $3: 25(181)$ & $8: 15(243)$ & 3.4 & 3.7 & 1.0757 \\
\hline 7. & 463.6 & 464.5 & 800 & 790 & 26.6 & 55.2 & $2: 17(162)$ & $8: 05(258)$ & 3.4 & 3.6 & 1.0757 \\
\hline
\end{tabular}

Table 5: Observations of Vanga Shodhana in Kulattha Kwatha during Dhalana Process

\begin{tabular}{|c|c|c|c|c|c|c|c|c|c|c|c|}
\hline \multirow[t]{2}{*}{ S. No. } & \multicolumn{2}{|c|}{ Wt of Vanga (gm) } & \multicolumn{2}{|c|}{$\begin{array}{c}\text { Volume of } \\
\text { Kwatha (ml) }\end{array}$} & \multicolumn{2}{|c|}{$\begin{array}{l}\text { Temperature. of } \\
\text { Kwatha }\left({ }^{0} \mathrm{C}\right)\end{array}$} & \multicolumn{2}{|c|}{$\begin{array}{l}\text { Started melting and completely } \\
\text { melted at which min and at what } \\
\text { temperature }\left({ }^{\circ} \mathrm{C}\right)\end{array}$} & \multicolumn{2}{|c|}{ pH of media } & \multirow[t]{2}{*}{$\begin{array}{l}\text { Specific } \\
\text { gravity }\end{array}$} \\
\hline & B & $\mathbf{A}$ & B & $\mathbf{A}$ & B & $\mathbf{A}$ & Started melting & Completion & B & $\mathbf{A}$ & \\
\hline 1. & 455 & 457.8 & 800 & 786 & 27.7 & 50.8 & $4: 07(205)$ & $8: 05(234)$ & 6.0 & 6.1 & 1.0795 \\
\hline 2. & 457.8 & 458.5 & 800 & 795 & 27.7 & 51 & $3: 05(203)$ & 9:07 (253) & 6.0 & 6.2 & 1.0792 \\
\hline 3. & 458.5 & 460.8 & 800 & 794 & 27.7 & 53 & $4: 52(232)$ & $8: 43(239)$ & 6.0 & 6.1 & 1.0792 \\
\hline 4. & 460.8 & 462 & 800 & 785 & 27.7 & 52 & $3: 57(228)$ & $8: 46(224)$ & 6.0 & 6.3 & 1.0796 \\
\hline 5. & 462 & 463.5 & 800 & 790 & 27.7 & 49 & $3: 39(222)$ & $8: 32(236)$ & 6.0 & 6.0 & 1.0795 \\
\hline 6. & 463.5 & 465 & 800 & 785 & 27.7 & 51 & $4: 40(196)$ & $10: 01(240)$ & 6.0 & 6.5 & 1.0800 \\
\hline 7. & 465 & 466.4 & 800 & 789 & 27.7 & 48 & 4:00 (219) & $10: 05(243)$ & 6.0 & 6.6 & 1.0838 \\
\hline
\end{tabular}

$*$ Here $\mathrm{B}=$ Before, $\mathrm{A}=$ After

Vishesha Shodhana of Vanga by Haridra (Turmeric) Churna and Nirgundi Patra Swarasa

Principle: Shodhana by Dhalana
Procedure: Samanya Shodhita Vanga was taken in a ladle and heated up to melting. Nirgundi Patra Swarasa mixed with Haridra (Turmeric) Churna was kept in Pittahara Yantra; Molten Vanga was poured into it. After cooling, Vanga was collected and same procedure was repeated for two more times. Each time fresh Nirgundi Patra Swarasa mixed with Haridra (Turmeric) Churna was used. (Table 6$)^{7}$ 
Table 6: Observations of Vanga Shodhana in Nirgundi Patra Swarasa mixed with Haridra (Turmeric) Churna during Dhalana process

\begin{tabular}{|c|c|c|c|c|c|c|c|c|c|c|c|}
\hline \multirow[t]{2}{*}{ S. No. } & \multicolumn{2}{|c|}{$\begin{array}{l}\text { Wt of Vanga } \\
\text { (gm) }\end{array}$} & \multicolumn{2}{|c|}{$\begin{array}{c}\text { Volume of } \\
\text { Swarasa (ml) }\end{array}$} & \multicolumn{2}{|c|}{$\begin{array}{l}\text { Temperature. of } \\
\text { Swarasa }\left({ }^{0} \mathbf{C}\right)\end{array}$} & \multicolumn{2}{|c|}{$\begin{array}{l}\text { Started melting and completely } \\
\text { melted at which min and at what } \\
\text { temperature }\left({ }^{\circ} \mathrm{C}\right)\end{array}$} & \multicolumn{2}{|c|}{$\begin{array}{l}\mathrm{pH} \text { of } \\
\text { media }\end{array}$} & \multirow[t]{2}{*}{$\begin{array}{l}\text { Specific } \\
\text { gravity }\end{array}$} \\
\hline & Before & After & B & $\mathbf{A}$ & B & $\mathbf{A}$ & Started melting & Completion & B & $\mathbf{A}$ & \\
\hline 1. & 459.6 & 462.4 & 800 & 780 & 30 & 49 & $2: 25(203)$ & $6: 05(238)$ & 5.5 & 5.8 & 1.0808 \\
\hline 2. & 464.3 & 465 & 800 & 785 & 30 & 51 & $3: 35(211)$ & $10: 27(257)$ & 5.5 & 5.7 & 1.0804 \\
\hline 3. & 466.6 & 468 & 800 & 787 & 30 & 48 & $6: 32(160)$ & $11: 37(261)$ & 5.5 & 5.9 & 1.0808 \\
\hline
\end{tabular}

Table 7: Observations of weight of Vanga during Vanga Shodhana in all Dhalana process

\begin{tabular}{|c|c|c|c|c|c|}
\hline S. No. & $\begin{array}{c}\text { Media taken for Shodhana/ } \\
\text { Dhalana }\end{array}$ & $\begin{array}{c}\text { Total Ashodhita Vanga } \\
\text { Taken progressively (gm) }\end{array}$ & $\begin{array}{c}\text { Suddha Vanga obtained } \\
\text { after Quenching (gm) }\end{array}$ & $\begin{array}{c}\text { Weight of Vanga } \\
\text { after Drying (gm) }\end{array}$ & $\begin{array}{c}\text { Change in } \\
\text { weight (gm) }\end{array}$ \\
\hline $\mathbf{1 .}$ & Tila Taila & 470 & 477.3 & 476 & $+6 \mathrm{gm}$ \\
\hline $\mathbf{2 .}$ & Takra & 476 & 492 & 480 & $+4 \mathrm{gm}$ \\
\hline $\mathbf{3}$. & Gomutra & 480 & 464.4 & 452.5 & $-17.5 \mathrm{gm}$ \\
\hline $\mathbf{4 .}$ & Kanji & 452.5 & 464.5 & 455 & $+2.5 \mathrm{gm}$ \\
\hline $\mathbf{5 .}$ & Kulattha Kwath & 455 & 466.4 & 459.6 & $+4.6 \mathrm{gm}$ \\
\hline $\mathbf{6 .}$ & $\begin{array}{c}\text { Haridra (Turmeric) Churna } \\
\text { Nirgundi Patra Swarasa }\end{array}$ & 459.6 & 468 & 463 & $+3.4 \mathrm{gm}$ \\
\hline
\end{tabular}

\section{Vanga Jarana}

Jarana process is to assimilate or digest the herbs in melted Vanga metal. ${ }^{8}$

Table 8: Weight of used drug materials in Jarana

\begin{tabular}{|c|c|c|c|}
\hline S. No. & Materials used & Botanical names & Wt. \\
\hline $\mathbf{1 .}$ & Shodhita Vanga & Stannum & $463 \mathrm{gm}$ \\
\hline $\mathbf{2 .}$ & Haridra (Turmeric) & Curcuma longa Linn. & $70 \mathrm{gm}$ \\
\hline $\mathbf{3 .}$ & Ajawain/Yavani & Trachyspermum ammi Linn. & $56 \mathrm{gm}$ \\
\hline $\mathbf{4 .}$ & Lavanga & Syzygium aromaticum Linn. & $44 \mathrm{gm}$ \\
\hline $\mathbf{5 .}$ & Imali Chhal & Tamarindus indica & $132 \mathrm{gm}$ \\
\hline $\mathbf{6 .}$ & Jeeraka & Cuminum cyminum Linn. & $30 \mathrm{gm}$ \\
\hline $\mathbf{7 .}$ & Apamarga Panchanga & Achyranthes aspera Linn. & $130 \mathrm{gm}$ \\
\hline $\mathbf{8 .}$ & Pippali Chhal & Ficus religiosa Linn. & $130 \mathrm{gm}$ \\
\hline
\end{tabular}

Procedure: All the herbal drugs were dried under sunlight and pulverized to form coarse churna and was collected in a tray. Shuddha Vanga was taken in wide mouthed iron vessel (Kadhahi) and the vessel was placed over intense fire. To the molten Shuddha Vanga, little by little amount of Haridra (Turmeric), Ajawain, Lavanga, Pippali Chhal, Imali Chhal, Jeeraka and Apamarga were added in respective order (Table 8). These were rubbed thoroughly with the base of a big iron spoon in the Kadhahi. The process was continued till all the Shodhita Vanga was turned into fine powder form completely. All the powder was collected at the centre, closed by a Sharava and intense heat was given for three hours. The fire was withdrawn after the bottom of iron pan turned red hot and then allowed to cool down.

Table 9: Results after Jarana of Shodhita Vanga

\begin{tabular}{|c|c|c|c|c|c|}
\hline Wt. of Shodhita Vanga & $\begin{array}{c}\text { Wt. of Jarana } \\
\text { dravya }\end{array}$ & Duration & $\begin{array}{c}\text { Wt. of Vanga after } \\
\text { Jarana }\end{array}$ & Weight loss \\
\hline $463 \mathrm{gm}$ & $534 \mathrm{gm}$ & $10.30 \mathrm{Hours}$ & $440 \mathrm{gm}$ & $23 \mathrm{gm}(5.2 \%)$ \\
\hline
\end{tabular}

Special note: After Jarana total 440 gm Vanga was obtained but for Marana 420 gm is used. Rest 20 gm bhasma was preserved for other laboratory studies

\section{Vanga Marana}

Procedure: Marana process or making of bhasma can be divided into two sub-divisions- Bhavana and Puta.

\section{Bhavana}

Bhavana is a process of pulverization or trituration by adding a liquid form material to a powder. Jarita Vanga was taken in a Khalvayantra (Mortar with pestle), Kumari Swarasa (Aloe vera juice) was added and triturated till it becomes suitable for pellets/ Chakrika preparation. Pellets of size $3 \mathrm{~cm}$ diameter and $0.5 \mathrm{~cm}$ thickness were prepared, dried in shade and weighed. Dried pellets were arranged in a Sharava (shallow earthen vessel) and kept one Sharava on other and by sealing the edges of both the
Sharava with the cloth pieces a round box shaped structure that is Samputa is prepared. ${ }^{10}$

\section{Puta}

Puta means heating process or measurement of heat needed to make bhasma. The prepared smeared Samputa was subjected to heat in electric muffle furnace by raising the temperature by $50^{\circ} \mathrm{C}$ at regular intervals of 30 minute. Till it reached $550^{\circ} \mathrm{C}$, maintained at this temperature for 1 hour, then switch off the furnace and allowed to cool down to room temperature. After self-cooling the Samputa was removed from the furnace, outer part cleaned and opened. Bhasma was weighed and subjected for Bhasma Pariksha. Same process was repeated for ten times to obtain Vanga Bhasma. After $10^{\text {th }}$ of Puta the Bhasma was compiled all the classical tests. (Table 10) ${ }^{9}$ 
Table 10: Observation during Marana of Vanga

\begin{tabular}{|c|c|c|c|c|c|c|c|}
\hline Date & $\begin{array}{l}\text { No. of } \\
\text { Puta }\end{array}$ & $\begin{array}{c}\text { Wt of Vanga } \\
\text { before Bhavana }\end{array}$ & $\begin{array}{c}\text { Wt of Bhavana } \\
\text { dravya }\end{array}$ & $\begin{array}{c}\text { Wt of Vanga } \\
\text { after Bhavana }\end{array}$ & $\begin{array}{c}\text { Given } \\
\text { temperature }\left({ }^{\circ} \mathrm{C}\right)\end{array}$ & $\begin{array}{l}\text { temperature given } \\
\text { for following hours }\end{array}$ & $\begin{array}{l}\text { Wt after } \\
\text { Puta }\end{array}$ \\
\hline $25 / 4 / 18$ & $1^{\mathrm{st}}$ & $420 \mathrm{gm}$ & $120 \mathrm{gm}$ & $427 \mathrm{gm}$ & $650^{\circ} \mathrm{C}$ & $4 \mathrm{hr} 30 \mathrm{~min}$ & $422 \mathrm{gm}$ \\
\hline $28 / 4 / 18$ & $2^{\text {nd }}$ & $422 \mathrm{gm}{ }^{\prime}$ & $100 \mathrm{gm}$ & $428 \mathrm{gm}$ & $550^{\circ} \mathrm{C}$ & $6 \mathrm{hr}$ & $424 \mathrm{gm}$ \\
\hline $5 / 5 / 18$ & $3^{\text {rd }}$ & $424 \mathrm{gm}$ & $120 \mathrm{gm}$ & $432 \mathrm{gm}$ & $550^{\circ} \mathrm{C}$ & $6 \mathrm{hr}$ & $429 \mathrm{gm}$ \\
\hline $7 / 5 / 18$ & $4^{\text {th }}$ & $429 \mathrm{gm}$ & $120 \mathrm{gm}$ & $435 \mathrm{gm}$ & $550^{\circ} \mathrm{C}$ & $6 \mathrm{hr}$ & $430 \mathrm{gm}$ \\
\hline $16 / 5 / 18$ & $5^{\text {th }}$ & $430 \mathrm{gm}$ & $120 \mathrm{gm}$ & $436 \mathrm{gm}$ & $550^{\circ} \mathrm{C}$ & $6 \mathrm{hr}$ & $432 \mathrm{gm}$ \\
\hline $19 / 5 / 18$ & $6^{\text {th }}$ & $432 \mathrm{gm}$ & $120 \mathrm{gm}$ & $440 \mathrm{gm}$ & $550^{\circ} \mathrm{C}$ & $6 \mathrm{hr}$ & $435 \mathrm{gm}$ \\
\hline $22 / 5 / 18$ & $7^{\text {th }}$ & $435 \mathrm{gm}$ & $120 \mathrm{gm}$ & $441 \mathrm{gm}$ & $550^{\circ} \mathrm{C}$ & $6 \mathrm{hr}$ & $437 \mathrm{gm}$ \\
\hline $31 / 5 / 18$ & $8^{\text {th }}$ & $437 \mathrm{gm}$ & $120 \mathrm{gm}$ & $440 \mathrm{gm}$ & $550^{\circ} \mathrm{C}$ & $6 \mathrm{hr}$ & $437 \mathrm{gm}$ \\
\hline $9 / 6 / 18$ & $9^{\text {th }}$ & $437 \mathrm{gm}$ & $120 \mathrm{gm}$ & $443 \mathrm{gm}$ & $550^{\circ} \mathrm{C}$ & $6 \mathrm{hr}$ & $437 \mathrm{gm}$ \\
\hline $15 / 6 / 18$ & $10^{\text {th }}$ & $437 \mathrm{gm}$ & $120 \mathrm{gm}$ & $452 \mathrm{gm}$ & $550^{\circ} \mathrm{C}$ & $6 \mathrm{hr}$ & $438 \mathrm{gm}$ \\
\hline
\end{tabular}

\section{Bhasma Pariksha}

The prepared sample of Vanga Bhasma was subjected for classical tests/examinations to check the quality and it was seen that the sample complied with all the tests i.e. Rekhapurnatva (filling in between the fingerprints), Varitaratva (swim/floats over water), Unama (rice particle held on bhasma both floating over water), Nishchandrata (not any lustureness like of metal particle), Niswadu (tasteless) etc.

\section{RESULTS AND DISCUSSION}

As such the Rasa Shastra and Bhaishajya Kalpana have laid emphasis on cautious approach in the manufacturing of medicines. It has given due importance from starting material to finished product. In Classics the Rasa Aushadhis have given more importance over the Kashtha Aushadhis (herbal drugs) because of less dose sufficiency, palatability properties and they give instant Aarogya or relief in comparison to Herbal preparations ${ }^{11}$. In present study total 470 gm of raw Vanga was taken, after Shodhana process $463 \mathrm{gm}$ Vanga was obtained. Further by the process of Jarana 440 gm Vanga was yield. From which 420 gm was used in Marana process, from which ultimately total bhasma of Vanga obtained was $438 \mathrm{gm}$.

\section{Shodhana}

The Vanga was subjected to both Samanya and Vishesha Shodhan following the method mentioned in Rasa Ratna Samucchaya. It took two months' time for total completion of the Samanya shodhana. (Table 7)

\section{Dhalana in Tila Taila}

The tila taila was change from initial brownish tinge to little dark in colour. Almost $15 \mathrm{ml}$ of oil was lost on an average after every quenching and after every pouring the oil acquired increase in temperature of $30-40^{\circ} \mathrm{C}$. The Vanga started melting in 2 minute and took nearly 6 minutes for complete melting. The reason for early melting is might be due to catching of fire by the tail adhered to Vanga after $1^{\text {st }}$ pouring. (Table 1 )

\section{Dhalana in Takra}

The takra was procured from Saras dairy. The $\mathrm{pH}$ of the original takra was acidic with the readings of 4.4 which were altered by 2 points after decimal. The time for complete melting took little longer time as the water content present in the takra made the metal to melt late. The takra showed the curdled appearance be due to pouring of the hot molten metal might has made coagulated the suspended particles An Increase of $7 \mathrm{~g}$ in weight was noticed might be due to presence of some remnant portion of takra. (Table 2)

\section{Dhalana in Gomutra}

The Gomutra was procured from local cowshed and the $\mathrm{pH}$ was weakly alkaline in nature which was changed by few points following decimal after pouring of hot molten metal. The specific gravity also changed following pouring as most of the water content vaporized during the process and the changes took place in suspending materials. The emitting of the ammonia smell because the media used was urine. (Table 3 )

\section{Dhalana in Kanji}

In Preparation of kanji the time taken for the completion was 1month time, the reason was because it was manufactured during the winter season. The $\mathrm{pH}$ of the filtrate was 3.4 means acidic. The total Kanji yield was $12 \mathrm{~L}$ in which solid content was of $1.15 \%$. No much variation either in volume reduction, $\mathrm{pH}$ or specific gravity etc following Shodhana or quenching in Kanji. (Table 4)

\section{Dhalana in Kulattha Kwath}

The Kwatha showed weakly acidic $\mathrm{pH}$ as evident by the $\mathrm{pH}$ value of 6.5 and with the total solid content of $12.5 \%$. In Kulattha kwatha also no noticeable change except specific gravity was observed. (Table 5)

\section{Dhalana in Haridra Churna and Nirgundi Patra Swarasa}

Swarasa obtained showing acidic $\mathrm{pH}$ of 5.5. By the end of the process most of the Vanga was converted to powder form. Overall, after Vishesha Shodhana a loss in weight by $3.4 \mathrm{gm}$ $(0.7234 \%)$ was noticed which was very minimum in terms and the loss was within normal limits. (Table 6)

\section{Jarana}

The Jarana process was carried out following the reference mentioned in Siddha Bhaishaja Manimala deviating from the general Apamarga Panchanga etc drugs since the final product to be explored for its effect in diabetes hence the method mentioned in Siddha Bhaishaja Manimala was followed. Jarana process took almost 10 hours 30 minutes to complete. (Table 8,9)

\section{Marana}

After the first two Puta color of Chakrikas was grayish white and hard in consistency. The color was just on the outer surface of Chakrikas which appeared as a coating. When the Chakrikas were 
broken inner surface was dull white. In the successive Putas the color changed from grayish white to white and the consistency changed from hard to soft. After $3^{\text {rd }}$ and $4^{\text {th }}$ Putas all the Chakrikas were found broken in the form of powder and was smooth in touch. After $5^{\text {th }}$ and $6^{\text {th }}$ Puta bhasma became very soft in touch and the color of the Bhasma became dull white. After ten Putas Bhasma became very fine, and easily passed through 200 Mesh. In each Puta the maximum temperature was maintained for one hour, which was increased up to $550^{\circ} \mathrm{C}$ in all Putas. Increase in weight of Vanga bhasma was also noted after each Puta. After drying of upper surface, the pellets were turned upside down to ensure proper drying of whole material. It took 10 Puta for preparing Vanga Bhasma. In Puta process temperature was raised gradually up to $550^{\circ} \mathrm{C}$ and maintained for 1 hour. Some difference was observed before and after weight of Jarita and Marita bhasma may be due to adding up of some substance during levigation and during marana oxidation of the Vanga happened, so it increased some weight. All the classical parameter of Bhasma Pariksha was passed by the Marita bhasma after $10^{\text {th }}$ Puta. (Table 10)

\section{CONCLUSION}

Vanga Bhasma is prepared following the classical references i.e. Rasa Ratna Samucchaya, Siddha Bheshaja Manimala, Rasamrita etc. and prepared bhasma is tasteless, odorless and very fine, hence complies all the Bhasma Pariksha mentioned in classics. The present study can be a platform for the further research works for generating the safety and efficacy data to use Bhasma in disease concern.

\section{REFERENCES}

1. Rasa Ratna Samucchaya, Shri Vaidyapati Singhgupt Vagbhatacharya, Vigyan Bodhini Hindi commentary by Professor Duttatreya Kulkarni, Part I, Meharchand Lacchmandas Publications, New Delhi, Reprint year, Chapter 5/1; 2007. p. 89.

2. Rasa Tarangani, Shri Sadananda Sharma, edited by Kashinath Shastri, Dwitiya Taranga, chapter name Paribhasha Vigyaniya, $8^{\text {th }}$ edition, Motilal Banarasidas, Delhi, Year; Shloka 36; 2014. p. 18.

3. Rasa Ratna Samucchaya, Shri Vaidyapati Singhgupt Vagbhatacharya, Vigyan Bodhini Hindi commentary by Professor Duttatreya Kulkarni, Part I, Meharchand
Lacchmandas Publications, New Delhi, Reprint year, Chapter 5/155; 2007. p. 124.

4. Rasa Ratna Samucchaya, Shri Vaidyapati Singhgupt Vagbhatacharya, Vigyan Bodhini Hindi commentary by Professor Duttatreya Kulkarni, Part I, Meharchand Lacchmandas Publications, New Delhi, Reprint year, Chapter 11, Kanjika Nirmana; 2007. p. 217.

5. Sharangadhara Samhita, Acharya Sharangadhara, Jiwanprada Hindi commentary, by Dr. Shailaja Shrivastava, Chaukhambha Orientalia, Varanasi; Reprint year, Madhyam Khanda, Chapter 2, Shloka 1-2; 2016. p. 135.

6. Rasa Ratna Samucchaya, Shri Vaidyapati Singhgupt Vagbhatacharya, Vigyan Bodhini Hindi commentary by Professor Duttatreya Kulkarni, Part I, Meharchand Lacchmandas Publications, New Delhi, Reprint year, Chapter 5/13; 2007. p. 93.

7. Rasa Ratna Samucchaya, Shri Vaidyapati Singhgupt Vagbhatacharya, Vigyan Bodhini Hindi commentary by Professor Duttatreya Kulkarni, Part I, Meharchand Lacchmandas Publications, New Delhi, Reprint year, Chapter 5/156; 2007. p. 124

8. Siddha Bheshaja Manimala, Mahakavi Sri Krishnaram Bhatta, Vaishwanara Hindi commentary by Sri R. Kaladhara Bhatta, $4^{\text {th }}$ edition, Chaukhambha Krishnadas Academy, Varanasi; Year, Chaturtha Guccha, Chapter name Prameha Chikitsa, Shloka 2-3; 2008. p. 251.

9. Rasamrita, Yadavji Trikamji Acharya, Commentary by Dr. Devnath Singh Gautam, Chaukhamba Surabharati Prakashan, Varanasi; Year, Chapter $3^{\text {rd }}$ Loha Vigyaniya, Shloka 94; 2014. p. 45.

10. Rasa Tarangani, Shri Sadananda Sharma, edited by Kashinath Shastri, Dwitiya Taranga, Chapter name Paribhasha Vigyaniya, $8^{\text {th }}$ edition, Motilal Banarasidas, Delhi, Year; Shloka 49; 2014. p. 21.

11. Rasa Ratna Samucchaya, Sri Vagbhatta, Tatvartha Vibodhini Hindi commentary by Pt. Dharmananda Sharma, $2^{\text {nd }}$ edition, edited by Atrideva Gupt, Motilal Banarasidas, Delhi; reprint year, Chapter $28^{\text {th }}$, Loha kalpa, Shloka 1; 1996. p. 459.

\section{Cite this article as:}

Manish Kumar Saini et al. Pharmaceutical study of Vanga Bhasma. Int. J. Res. Ayurveda Pharm. 2020;11(5):77-82 http://dx.doi.org/10.7897/2277-4343.1105145 